\title{
Growth, carbon dioxide assimilation capacity and water-use efficiency of Pinus pinea $L$ seedlings inoculated with different ectomycorrhizal fungi
}

\author{
JM Guehl $^{1 \star}, \mathrm{D}_{\text {Mousain }}^{2}$, G Falconnet ${ }^{3}, \mathrm{~J} \mathrm{Gruez}^{3}$ \\ ${ }^{1}$ INRA, Centre de Recherches de Nancy, Laboratoire de Bioclimatologie-Ecophysiologie \\ Forestiere, Champenoux, 54280 Seichamps ; \\ 2 INRA, Centre de Recherches de Montpellier, Laboratoire de Recherches sur les Sym- \\ biotes des Racines, 34060 Montpellier ; \\ 3 CEMAGREF, Groupement d'Aix-en-Provence, Division des Techniques Forestieres Mediter- \\ ranéennes, Le Tholonet, 13610 Aix-en-Provence, France
}

(Received 28 June 1989; accepted 8 January 1990)

\begin{abstract}
Summary - Three months after sowing, seedlings of Pinus pinea $L$ grown in a nursery on a perlite-Sphagnum peat mixture were inoculated with different ectomycorrhizal fungi: Rhizopogon roseolus and Suillus collinitus (2 strains: 1 and 2). The growth medium was maintained well-watered and was fertilized with a dilute Coïc-Lesaint $\left(N, P, K, 3,2,7.5 \mathrm{~g} \mathrm{I}^{-1}\right)$ solution. Fertilization was stopped at the end of the first growing season (October) and growth and gas exchange parameters of the seedlings were assessed prior to the beginning of their second growth season. Inoculation with the $2 S$ collinitus strains led to the greatest plant elongation, but biomass growth was greatest with $R$ roseolus. Whole plant $\mathrm{CO}_{2}$ assimilation capacity in the $R$ roseolus treatment was 1.83 times that in the control treatment and 1.38 times that in the $S$ collinitus 2 treatment. The plants infected by $R$ roseolus and $S$ collinitus 1 had similar whole plant $\mathrm{CO}_{2}$ assimilation capacities, but root and total plant biomass were significantly higher in the $R$ roseolus treatment. This difference could be due partly to greater carbon diversion by the fungal associate in the case of $S$ collinitus 1 . Mean water-use efficiency (WUE $=\mathrm{CO}_{2}$ assimilation rate/transpiration rate) of the inoculated seedlings (pooled mean value $\left.7.29 \mathrm{~mol} \mathrm{kmol}^{-1}\right)$ was significantly $(P<0.05)$ higher than that of the controls $\left(5.06 \mathrm{~mol} \mathrm{kmol}^{-1}\right)$. This is linked to the double tendency, neither being statistically significant, of the infected plants to exhibit higher $\mathrm{CO}_{2}$ assimilation rates and lower transpiration rates than the controls.
\end{abstract}

Pinus pinea / ectomycorrhiza / growth / $\mathrm{CO}_{2}$ assimilation / water-use efficiency

Résumé - Crolssance, capacité d'assimilation de $\mathrm{CO}_{2}$ et efficlence de l'eau de plants de Pinus pinea $L$ inoculés par différents champignons ectomycorhiziens. Des plants de Pinus pinea $L$ ágés de 3 mois et cultivés en pépinière sur un subtrat à base de perlite et de 
tourbe blonde de Sphaigne, ont été inoculés avec différents champignons ectomycorhiziens : Rhizopogon roseolus et Suillus collinitus (2 souches, 1 et 2). Le substrat était maintenu en permanence à un niveau hydrique non limitant et était fertilisé à l'aide d'une solution diluee de type Coïc-Lesaint $\left(N, P, K ; 3,2,7.5 \mathrm{~g} \Gamma^{-1}\right)$. La fertilisation a été interrompue à la fin de la première saison de végétation des plants (octobre). On a mesuré les caracteristiques de taille et de biomasse des plants ainsi que les échanges gazeux de $\mathrm{CO}_{2}$ et $\mathrm{H}_{2} \mathrm{O}$ avant le début de la seconde saison de végétation (février). La hauteur des plants était la plus forte pour les plants inocules avec les 2 souches de $\mathrm{S}$ collinitus, mais la croissance pondérale état la plus élevée dans le cas des plants inoculés avec R roseolus. La capacité totale d'assimilation de $\mathrm{CO}_{2}$ des plants inoculés par $\mathrm{R}$ roseolus représentait $183 \%$ par rapport à la capacité des plants non mycorhizés et $138 \%$ par rapport au traitement $\mathrm{S}$ collinitus 2. Les plants inoculés par $\mathrm{R}$ roseolus et $\mathrm{S}$ collinitus 1 etaient caracterisés par des capacites totales d'assimilation de $\mathrm{CO}_{2}$ similaires, mais la biomasse racinaire ainsi que la biomasse totale des plants étaient plus élevees dans le cas du traitement $\mathrm{R}$ roseolus. Cette différence pourrait être liee, du moins partiellement, à une utilisation plus importante du carbone assimile, par l'associé fongique, dans le cas de S collinitus 1. L'efficience de l'eau WUE = taux d'assimilation de $\mathrm{CO}_{2}$ /taux de transpiration) moyenne des plants mycorhizés (valeur moyenne générale $7.29 \mathrm{~mol} \mathrm{kmor}^{-1}$ ) était significativement supérieure $(\mathrm{P}<0.05)$ à celle des plants non mycorhizés $\left(5.06 \mathrm{~mol} \mathrm{kmor}^{-1}\right)$. Cela est à relier à la double tendance, non statistiquement significative pour chacune des 2 composantes considérées separement, des plants mycorhizés à présenter des valeurs moyennes de taux d'assimilation de $\mathrm{CO}_{2}$ (A) plus élevées et de taux de transpiration (E) plus faibles que les plants non mycorhizés.

Pinus pinea / ectomycorhize / croissance / assimilation de $\mathrm{CO}_{2} /$ efficience de l'eau

\section{INTRODUCTION}

Ectomycorrhizal infection is generally accompanied by alterations in the host plant $\mathrm{CO}_{2}$ assimilation capacity with effects on both leaf area and assimilation rate (A) (Ekwebelam and Reid, 1983; Harley and Smith, 1983; Paul et al, 1985; Jones and Hutchinson, 1988). Part of the $\mathrm{C}$ fixed, $4 \%$ to $17 \%$ as reported by Paul et al (1985), is diverted towards the fungal associate to meet its metabolic requirements (Martin et al, 1987). Despite this specific C cost, the increase of $\mathrm{CO}_{2}$ assimilation provided by mycorrhizal infection is often sufficient to achieve enhanced plant growth (Ekwelebam and Reid, 1983; Harley and Smith, 1983). The mechanisms most commonly proposed for explaining enhanced photosynthesis in mycorrhizal plants involve aspects of $P$ and $N$ nutrition, source-sink regulation and hormones (Harley and Smith, 1983).

Some authors have also shown that fungi can directly affect plant water relations. Duddrige et al (1980) demonstrated that the mycelium of Suillus bovinus could absorb tritiated water which was then transported through the mycelial network to the host plant. Brownlee et al (1983) and Boyd et al (1986) found that physiologically significant quantities of water were being transported through such mycelia, since the cutting of mycelial strands connecting plants to moist peat led to a rapid decrease in leaf water potential, transpiration and photosynthesis of the host plant. Jones and Hutchinson (1988) observed higher transpiration rates in Betula papyrifera seedlings inoculated with Scleroderma flavidum than in non inoculated seedlings.

Little attention has been paid to examining the effects of mycorrhizas on 
water-use efficiency (WUE = ratio of $\mathrm{CO}_{2}$ assimilation to transpiration) of host plants, yet WUE constitutes a major aspect of plant growth limitation in dry conditions and is subject to physiological regulation involving ontogenic adaptation (Wong et al, 1985; Guehl et al, 1988) and to short term changes in response to environmental factors (Cowan and Farquhar, 1977; Guehl and Aussenac, 1987).

The purpose of the present study was to assess growth, $\mathrm{CO}_{2}$ assimilation capacity and WUE in different ectomycorrhizal Pinus pinea seedlings under non-limiting water supply conditions.

\section{MATERIALS AND METHODS}

\section{Plant inoculation and growing conditions}

Isolates of the following ectomycorrhizal fungi were obtained from basidiocarps harvested in a Pinus pinea stand established on a calcareous sandy soil (La Grande Motte, Hérault, France): Suillus collinitus (ss. Flury nec ss. Sr.; 2 strains, 1 and 2) and Rhizopogon roseolus (Corda in Sturn). Mycelial inocula were grown in aseptic conditions for 7 weeks on a perlite-peat mixture $(4: 1, \mathrm{v} / \mathrm{v})$ moistened with a Pachlewski (Pachlewski, 1967) solution.

At the end of the winter 1986, seeds of Pinus pinea $L$. were germinated in a heated greenhouse on a perlite-Sphagnum peat mixture $(1: 1, \mathrm{v} / \mathrm{v})$ in $500 \mathrm{~cm}^{3}$ anti-coiling containers with 2 easily removable and replaceable sides (Riedacker, 1978). Three months after sowing, each seedling was inoculated with $50 \mathrm{ml}$ inoculum brought into contact with the roots by temporarily removing the 2 sides of the containers. The growth medium was maintained in a well watered state $(\mathrm{pF}<1.5)$ during the whole growth period. Before inoculation the containers were watered with water at $\mathrm{pH}$ 8.3, which adjusted the growth medium to $\mathrm{pH} 6.2$. After inoculation the containers were fertilized every other week with a dilute Coilc-Lesaint solution containing major $(N, P, K ; 3,2,7.5$
$10^{-2} \mathrm{~g}^{-1}$ ) and trace elements. Uninoculated and inoculated plants received the same fertilization (Moussain et al, 1988).

After inoculation, the plants were grown outside in uniform nursery conditions in Southern France (mediterranean climate) with $60 \%$ of the natural incident radiation at shoot level. Five months after inoculation the root colonization by the mycorrhizal fungi was assessed. The proportion of plants colonized by the inoculated fungi was 91 , 78 and $9 \%$ in $S$ collinitus 1 and 2 and $R$ roseolus, respectively. The mycorrhizal index (index ranging from 0 to 5 and representing the frequency of mycorrhizal tips versus the total number of root apices) of the colonized plants was 3.0 in the 2 treatments inoculated with $S$ collinitus and 2.5 in the $R$ roseolus treatment, control plants were nonmycorrhizal.

At the end of the growing season, in October 1986, fertilization was stopped and the plants were left in full sunlight conditions as is usual in forestry practice. In February 1987, 30 plants (only mycorrhizal plants for the 3 inoculated treatments and nonmycorrhizal control plants) were taken at random within each of the 4 treatments and transferred to Nancy (Northeastern France) where their gas exchange, biomass and size characteristics were assessed in controlled standardized conditions. Gas exchange measurements made at this time of year provide an estimation of the physiological status of the plant just prior to planting-out (Guehl et al, 1989). All the plants of the different treatments were dormant at the period of gas exchange measurements.

\section{Gas exchange and growth measurements}

Carbon dioxide and $\mathrm{H}_{2} \mathrm{O}$ gas exchange were measured with an open gas exchange system consisting of 3 assimilation chambers $\left(28 \times 15 \times 33 \mathrm{~cm}^{3}\right)$ connected in parallel and through which air was passed at a flow rate of $150 \mathrm{I} \mathrm{h}^{-1}$. Air temperature in the chambers was maintained at $22.0 \pm 0.5^{\circ} \mathrm{C}$. Photosynthetic photon flux density $(400-$ $700 \mathrm{~nm}$ ) at shoot level was $600 \mu \mathrm{mol} \cdot \mathrm{m}^{-2} \cdot \mathrm{s}^{-1}$ and was provided by high pressure sodium lamps (Sont, Philips). The $\mathrm{CO}_{2}$ molar fraction of the air entering the chamber was measured continuously with an ADC-225 MK2 IR- 
$\mathrm{GA}$ and was adjusted to $350 \pm 5 \mathrm{~Pa} \cdot \mathrm{MPa}^{-1}$. The difference in $\mathrm{CO}_{2}$ molar fraction between the airs entering and leaving the chambers was measured with a differential ADC-225 MK3 IRGA, alternately for periods of $3 \mathrm{~min}$ for the 3 chambers by means of an automated switching system. The dewpoint of the airs entering the chambers and of the different airs leaving the chambers was measured concurrently with the $\mathrm{CO}_{2}$ measurements with a dewpoint hygrometer (System 1100 DP, General Eastern). The air entering the chambers was maintained at $1380 \pm 40 \mathrm{~Pa}$ water vapour pressure, leading to leaf-to-air vapour molar fraction differences $(\Delta W)$ in the chambers of between 7.0 and $10.0 \mathrm{~Pa} \cdot \mathrm{kPa}^{-1}$, depending on the intensity of plant transpiration. Because transpiration, in turn, depends on $\Delta W$, and in order to permit comparisons between plants, corrections were made using appropriate formulae (Caemmerer and Farquhar, 1981) to set each value to a constant $\Delta W$ of 8.5 $\mathrm{Pa} \cdot \mathrm{KPa}^{-1}$. Gas exchange calculations were made on a needle dry-weight basis, giving $\mathrm{CO}_{2}$ assimilation rates (A) in $\mathrm{nmol} \cdot \mathrm{g}^{-1} \cdot \mathrm{s}^{-1}$ and transpiration rates (E) in $\mu \mathrm{mol} \cdot \mathrm{g}^{-1} \cdot \mathrm{s}^{-1}$ Measurements of gas exchange rates were taken as the steady-state values after a period of 1-2 $\mathrm{h}$ adjustment by the seedlings to the assimilation chamber conditions.

After gas exchange measurements, the plants were separated into their different components (whole root system, needles, nonphotosynthetic aerial parts), oven dried at $80{ }^{\circ} \mathrm{C}$ for $48 \mathrm{~h}$, and the different dryweights were assessed. There were 9 replicates for the uninoculated treatment (controls), 13 for the $R$ roseolus treatment which had the highest biomass growth, and 6 for each of the 25 collinitus treatments. In addition, $5 S$ collinitus 2 infected plants were used only for whole plant gas exchange measurements. In 5 individuals of each of the controls $R$ roseolus, and $S$ collinitus 1 treatments of the total projected needle area of the plants was also determined with an image analysis system (TAS) in order to assess the specific dry-weight of the needles (dry weight/area ratio). For these different types of measurements, samples were taken randomly within the different treatments. For all the variables assessed, differences between treatments were tested by means of Scheffe's multiple comparison test.

\section{RESULTS}

\section{Size and biomass growth}

Maximum height growth of the plants (table I) occurred with the treatments $S$ collinitus 1 and $S$ collinitus 2 with values significantly greater than those of the control treatment. Growth in height of the $R$ roseolus plants was not

Table I. Growth characteristics of one year old Pinus pinea seedlings inoculated with ectomycorrhizal fungi. Means within a column not sharing a common letter differ significantly $(P<0.05)$ by Scheffe's multiple comparison test.

\begin{tabular}{lccccccc}
\hline $\begin{array}{c}\text { Treatment } \\
\text { and nb. } \\
\text { of replicates }\end{array}$ & $\begin{array}{c}\text { Root } \\
\text { collar } \\
\text { diameter }\end{array}$ & Height & $\begin{array}{c}\text { Root } \\
\text { dry } \\
\text { weight }\end{array}$ & $\begin{array}{c}\text { Shoot } \\
\text { dry } \\
\text { weight }\end{array}$ & $\begin{array}{c}\text { Total } \\
\text { dry } \\
\text { weight }\end{array}$ & $\begin{array}{c}\text { Root : } \\
\text { shoot } \\
\text { ratio }\end{array}$ & $\begin{array}{c}\text { Needle : } \\
\text { shoot } \\
\text { ratio }\end{array}$ \\
\hline Control (9) & $(\mathrm{mm})$ & $(\mathrm{mm})$ & $(\mathrm{g})$ & $(\mathrm{g})$ & $(\mathrm{g})$ & & \\
$R$ roseolus (13) & $4.24 \mathrm{a}$ & $172 \mathrm{~b}$ & $1.47 \mathrm{~b}$ & $1.83 \mathrm{~b}$ & $3.30 \mathrm{~b}$ & $0.81 \mathrm{a}$ & $0,66 \mathrm{a}$ \\
$S$ collinitus 1 (6) & $4.05 \mathrm{a}$ & $206 \mathrm{a} \mathrm{b}$ & $1.98 \mathrm{a}$ & $2.49 \mathrm{a}$ & $4.47 \mathrm{a}$ & $0.81 \mathrm{a}$ & $0,66 \mathrm{a}$ \\
$S$ collinitus 2(6) & $4.36 \mathrm{a}$ & $210 \mathrm{a}$ & $1.18 \mathrm{~b}$ & $2.01 \mathrm{a} \mathrm{b}$ & $3.19 \mathrm{~b}$ & $0.59 \mathrm{~b}$ & $0,67 \mathrm{a}$ \\
\hline
\end{tabular}


significantly different from that of the controls. No significant treatment effects were found for root collar diameter of the plants. The highest total dry weight occurred in the treatment $R$ roseolus, with a value significantly greater than those of the $S$ collinitus 1 and the control treatments, but not than that of $S$ collinitus 2. At the individual level, total plant dry weight (TDW, g) was poorly correlated with plant height $(H, \mathrm{~mm})(r=0.32, \mathrm{n}=34, P<0.05)$, and better correlated with root collar diameter $(D, \mathrm{~mm})$ (TDW $=1.33 \mathrm{D}-1.96$, $r=0.78, n=34, P<0.05)$ and with $\mathrm{H} \times \mathrm{D}^{2}\left(T D W=6.3510^{-4} H D^{2}+1.369\right.$, $r=0.83, n=34, P<0.05)$. Significant differences between treatments were found for the root/shoot ratio of the plants, with $S$ collinitus 1 having the lowest value (0.59). This low value was primarily due to low root dry weight in the $S$ collinitus 1 treatment, the estimated mean value being even less than in the control plants. The plants infected by $S$ collinitus 2 and $R$ roseolus had ratios not significantly different from that of the controls.

The $R$ roseolus infected plants had needle dry weights and areas significantly greater than those of the control plants (tables I and II), the values for the 2 treatments inoculated with the $S$ collinitus strains being intermediate. There was no treatment effect on needle/shoot ratio (table 1). The needles of the mycorrhizal plants had lower specific needle dry weights (table II, $S$ collinitus 2 was not measured) than the control plants.

\section{Carbon dioxide assimilation capacity}

There was no significant treatment effect relative to A (table III) though large differences were measured among treatments. However, significant treatment effects were noticed relative to whole plant $\mathrm{CO}_{2}$ assimilation capacity, the capacity of the $R$ roseolus plants $\left(50.5 \mathrm{nmol} \cdot \mathrm{s}^{-1}\right)$ being 1.81 times greater than that of the control plants and 1.38 times greater than that of the $S$ collinitus 2 infected plants. There was no close relationship between the mean treatment values of total plant dry weight (table I) and whole plant $\mathrm{CO}_{2}$ assimilation capacity measured at the end of the growing season (table III), since the $S$ collinitus 2 infected plants had higher dry weights than the $S \mathrm{col}$ linitus 1 infected plants, but lower $\mathrm{CO}_{2}$ assimilation capacities.

Table II. Needle area, dry weight and specific dry weight of 1-year old Pinus pinea seedlings inoculated with ectomycorrhizal fungi. Means within a column not sharing a common letter differ significantly $(P<0.05)$ by Scheffe's multiple comparison test.

\begin{tabular}{lccc}
\hline $\begin{array}{c}\text { Treatment } \\
\text { and no. } \\
\text { of replicates }\end{array}$ & $\begin{array}{c}\text { Needle area } \\
\left(10^{-2} \mathrm{~m}^{2}\right)\end{array}$ & $\begin{array}{c}\text { Needle dry weight } \\
(g)\end{array}$ & $\begin{array}{c}\text { Specific needle } \\
\text { dry weight } \\
\left(10^{2} \mathrm{~g} \mathrm{~m}^{-2}\right)\end{array}$ \\
\hline Control (5) & $0.83 \mathrm{~b}$ & $1.02 \mathrm{~b}$ & $1.22 \mathrm{a}$ \\
R. roseolus $(5)$ & $1.38 \mathrm{a}$ & $1.62 \mathrm{a}$ & $1.18 \mathrm{a} \mathrm{b}$ \\
S. collinitus $1(5)$ & $1.15 \mathrm{a} \mathrm{b}$ & $1.34 \mathrm{a} \mathrm{b}$ & $1.17 \mathrm{~b}$ \\
\hline
\end{tabular}


Table III. $\mathrm{CO}_{2}$ and $\mathrm{H}_{2} \mathrm{O}$ gas exchange parameters of one year old Pinus pinea seedlings inoculated with ectomycorrhizal fungi. Means within a columnn not sharing a common letter differ significantly $(P<0.05)$ by Scheffe's multiple comparison test.

\begin{tabular}{|c|c|c|c|c|c|}
\hline $\begin{array}{l}\text { Treatment } \\
\text { and No. } \\
\text { of replicates }\end{array}$ & $\begin{array}{c}\text { Needle } \\
\text { dry } \\
\text { weight } \\
\text { (g) }\end{array}$ & $\begin{array}{c}\mathrm{CO}_{2} \\
\text { assimilation } \\
\text { rate }(\mathrm{A}, \\
\left.\mathrm{nmol} \cdot \mathrm{g}^{-1} \cdot \mathrm{s}^{-1}\right)\end{array}$ & $\begin{array}{l}\text { Transpiration } \\
\text { rate } E \\
\mu m o l g^{-1} \cdot s^{-1}\end{array}$ & $\begin{array}{c}\text { Total plant } \\
\mathrm{CO}_{2} \\
\text { assimi-lation } \\
\left(\mathrm{nmol} \cdot \mathrm{s}^{-1}\right)\end{array}$ & $\begin{array}{c}\text { Water use } \\
\text { efficiency } \\
A E_{,} \\
\left(1 \sigma^{3}\right)\end{array}$ \\
\hline $\begin{array}{l}\text { Control (9) } \\
R \text { roseolus (13) } \\
S \text { collinitus } 1(6) \\
S \text { collinitus } 2(6)\end{array}$ & $\begin{array}{l}1.21 \mathrm{~b} \\
1.65 \mathrm{a} \\
1.34 \mathrm{a} \mathrm{b} \\
1.40 \mathrm{ab}\end{array}$ & $\begin{array}{l}23.3 \mathrm{a} \\
30.8 \mathrm{a} \\
32.4 \mathrm{a} \\
27.3 \mathrm{a}\end{array}$ & $\begin{array}{l}4.62 \mathrm{a} \\
4.47 \mathrm{a} \\
4.24 \mathrm{a} \\
3.89 \mathrm{a}\end{array}$ & $\begin{array}{l}27.9 \mathrm{~b} \\
50.5 \mathrm{a} \\
44.0 \mathrm{ab} \\
36.5 \mathrm{~b}\end{array}$ & $\begin{array}{l}5.06 \mathrm{~b} \\
7.21 \mathrm{a} \\
7.63 \mathrm{a} \\
7.04 \mathrm{a}\end{array}$ \\
\hline
\end{tabular}

In fig la the individual total dry weight values of the plants are plotted against their total $\mathrm{CO}_{2}$ assimilation capacities; there was only a weak linkage between these 2 variables. No relationship was observed between the total dry weight of the plants and their $A$ values (fig $1 \mathrm{~b}$ ), thus indicating that the weak dependence noticed in fig $1 \mathrm{a}$ is attributable solely to the correlatior. between total dry weight and needle dry weight of the plants (fig 1c).

\section{Water-use efficiency}

The mean transpiration rates of the mycorrhizal plants (table III) were not significantly different from those of the control plants. However, WUE in the control plants $\left(5.06 \mathrm{~mol} \mathrm{kmol}{ }^{-1}\right)$ was markedly and significantly lower than that of the infected plants (pooled mean value $=7.29 \mathrm{~mol} \mathrm{kmol}^{-1}$ ). This is to be associated with the double tendency, neither being statistically significant, of the infected plants to exhibit higher $A$ and lower $E$ values (table III) than the controls. Fig $2 a$ gives an interesting insight into the WUE regulation at the individual level: the individual variability of the points rela-
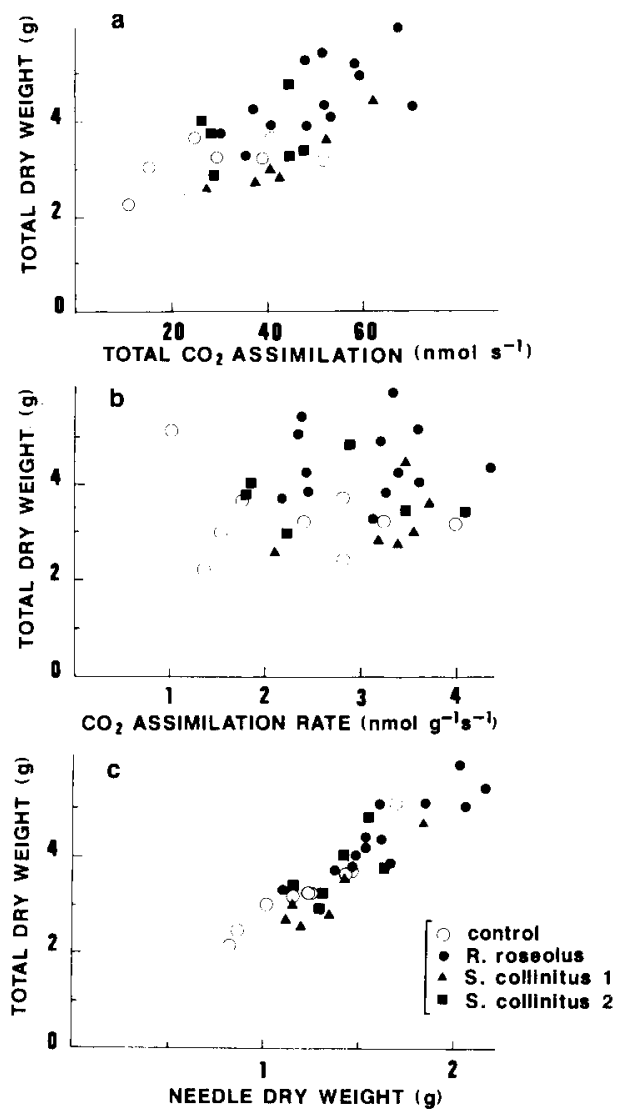

Fig 1a, b, c. Individual values of total dry-matter weight of Pinus pinea seedlings inoculated with different ectomycorrhizal fungi plotted against (a) their total assimilation capacity, (D) their $\mathrm{CO}_{2}$ assimilation rate $(A)$ and $(C)$ their needle dry weight. 
tive to the infected treatments (all treatments pooled) appears to be ordered along a unique linear relationship expressing almost proportionally between
$\mathrm{CO}_{2}$ assimilation and transpiration (constant WUE), since the $Y$-axis intercept of the regression line ( $Y=$ $5.57 X+6.50, r=0.82)$ was not signifi-
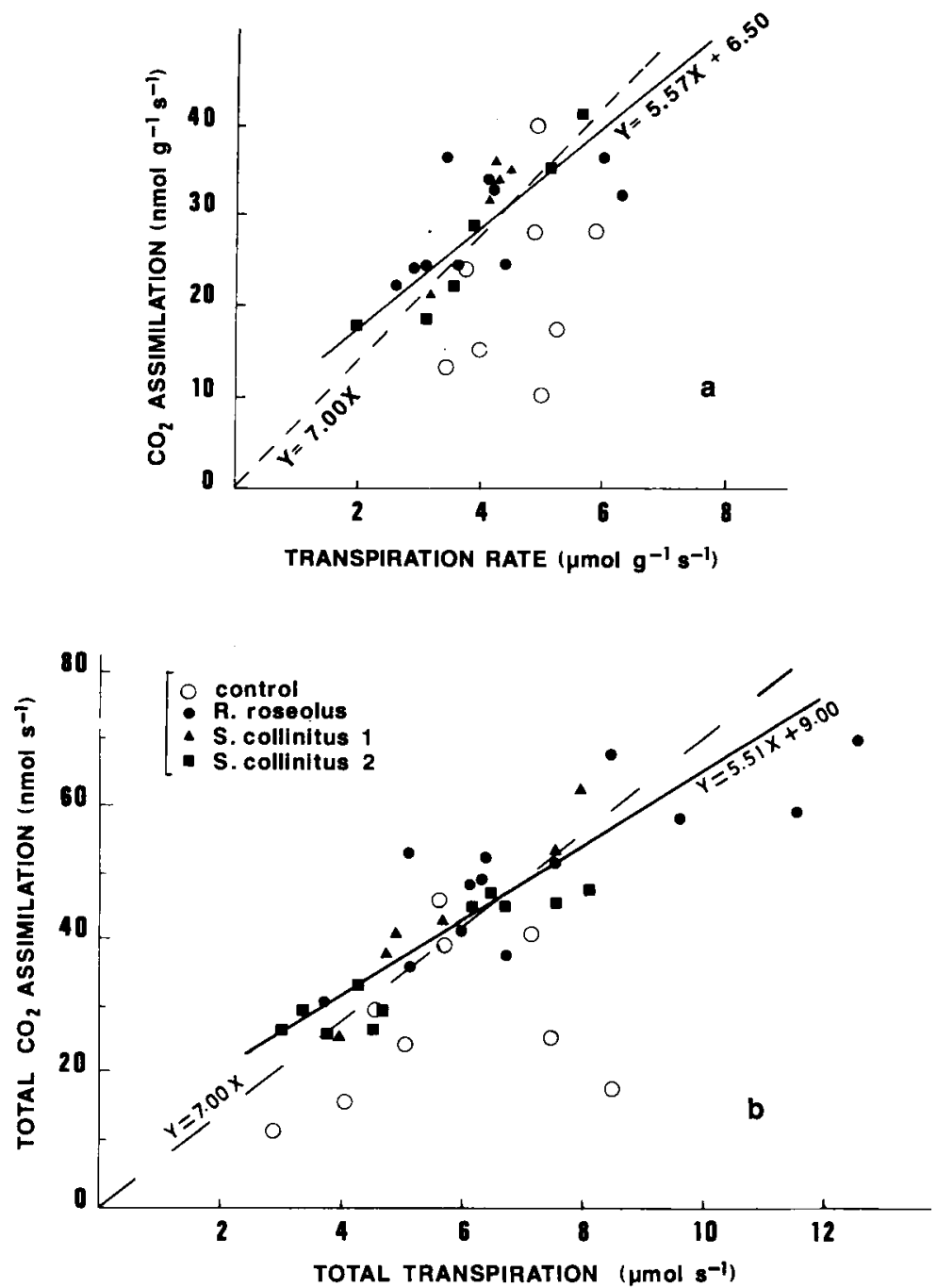

Fig 2a, b. (a) Carbon dioxide assimilation rate (A) of Pinus pinea seedlings inoculated with different ectomycorrhizal fungi in relation to transpiration rate $(E):(b)$, total plant $\mathrm{CO}_{2}$ assimilation in relation to total transpiration. Regression lines drawn in the figure refer to inoculated treatments only ; full line. orthogonal least square regression; broken line, regression line forced through the origin. $S$ collinitus 2 , $n=6$ in fig $2 \mathrm{a}$ and $n=11$ in fig $2 \mathrm{~b}$. 
cantly different from the origin. A regression line forced through the origin $(Y=7.00 X)$ has also been represented in fig $2 a$. The control plants did not exhibit such a control of WUE: 4 individuals out of 9 had WUE values identical to those of the inoculated plants, but 5 individuals had markedly lower WUE values, thus providing a clear discrimination between uninoculated and inoculated plants in figure $2 a$. The data in fig $2 b$ show the same discrimination in a total plant assimilation $v s$ transpiration graph.

\section{DISCUSSION}

Ectomycorrhizal infection by $R$ roseolus had a significant positive effect on biomass growth of Pinus pinea seedling raised over 1 growing season in nursery conditions, whereas there was no enhancing effect in seedlings infected by the $2 S$ collinitus strains. Ekwebelam and Reid (1983), Harley and Smith (1983), Tyminska et al (1986) have reported similar results indicating that the extent to which growth was affected by the infection will depend on the fungal species and strain used as mycobiont. It should be stressed here that mycorrhizal infection had differential effects on shoot height growth and biomass growth, since the $S$ collinitus 1 treatment produced the tallest plants without increasing the total plant biomass compared to the control plants. This can be somewhat misleading in field experiments in which height growth is often taken as an indicator of plant vigour.

The present study also provides some information regarding the biomass distribution between the different plant components and its modulation by mycorrhizal infection. In their review paper, Harley and Smith (1983) reported that in most cases ectomycorrhizal infection will reduce the root: shoot ratio. These authors noted that in the examples where the root/shoot ratio was found to be slightly enhanced by infection, the increase may be accounted for by the fungal sheath biomass if this were to comprise $20 \%$ of the weight of the roots. Our results (table 1) are consistent with these general findings, the root/shoot ratio of the infected plants being lower than ( $S$ collinitus 1 treatment) or equal to ( $R$ roseolus and $S$ collinitus 2 treatments) that of the control plants.

Whole plant $\mathrm{CO}_{2}$ assimilation was highest in the $R$ roseolus infected plants. Relatively high (though not significantly different from the controls) values were also found in the $S$ collinitus 1 and 2 treatments, but biomassand especially root biomass-growth was not enhanced in these latter treatments as compared to the controls. Whole plant $\mathrm{CO}_{2}$ assimilation did not exhibit significant differences between the $R$ roseolus and $S$ collinitus 1 treatments, but root and whole plant biomass were lower in the $S$ collinitus 1 treatment. Differential seasonal courses of growth and $\mathrm{CO}_{2}$ assimilation cannot be eliminated as an explanation for these discrepancies. These results may also suggest that in the $S$ collinitus infected plants $C$ allocation to the vegetative sinks of the host plant could be curtailed because of important $\mathrm{C}$ diversion to the mycobiont metabolic requirements (Paul et al, 1985; Martin et al, 1987). Further evidence for such an interpretation is provided by the low specific needle dry weights found in the $S$ collinitus 1 plants (table II), probably reflecting low needle carbohydrate contents (Ehret and Jolliffe, 1985) and high $\mathrm{C}$ sink activity (Harley and Smith, 
1983). The greater growth efficiency of the $R$ roseolus infected seedlings could be linked to lower fungal $C$ requirements (Harley and Smith, 1983; Paul et al 1985; Tyminska et al, 1986; Marshall and Perry, 1987) $R$ roseolus appears to be a very efficient fungus, worth select-ing for practical applications.

Enhanced whole plant $\mathrm{CO}_{2}$ assimilation capacity at the end of the growing season in the inoculated seedlings was probably due to higher values of both needle dry-weight and $A$ (table III), though the differences in assimilation rate were not statistically significant. In the absence of foliar nutrient determinations, it is not possible to assess here whether these effects and the large variability of $A$ and $E$ within the treatments are due to varying $N$ or $P$ nutritional status or to other factors.

Regardless of the physiological processes responsible for the high variability of $\mathrm{CO}_{2}$ assimilation both at the treatment (table III) and individual (fig 2) levels, $\mathrm{CO}_{2}$ assimilation and transpiration of the infected seedlings, measured under standard conditions, were in nearly constant proportion (figure 2). Such a coupling, reflecting near constancy of WUE, has been reported for variations due to mineral nutrition (Wong et al, 1985; Guehl et al, 1989).

A main result of the present study is the observation of the absence of coupling between $\mathrm{CO}_{2}$ assimilation and transpiration, as well as lower WUE in the control plants (fig 2). It might be suggested that this lack of stomatal control is linked to a low orthophosphate $(\mathrm{Pi})$ level in the needles of the nonmycorrhizal plants. Mousain (unpublished results) found very low $\mathrm{Pi}$ concentrations in the needles of juvenile nonmycorrhizal Pinus pinaster seedlings. Harris et al (1983) found that in leaf discs of Spinacia oleracea low
Pi led to a loss of stomatal control and wide stomatal apertures, while high $\mathrm{Pi}$ induced stomatal closure. In the same species, Herold (1978) observed that mannose and deoxyglucose induced wilting by metabolically sequestring $\mathrm{Pi}$. Further investigations are required to test this hypothesis in the case of coniferous species.

The results obtained in the present study might be of relevance to forestry practice. Guehl et al (1989) have observed that whole plant $\mathrm{CO}_{2}$ assimilation capacity was an important physiological determinant of survival after planting-out in Cedrus atlantica seedlings. Low $\mathrm{CO}_{2}$ assimilation capacities, plus lower and more variable WUE in non-inoculated seedlings, may, at least partly, explain the poor survival and initial growth after planting-out commonly observed in different plantation systems around the world in non-inoculated as compared to inoculated seedlings (Marx et al, 1977; Le Tacon et al, 1987).

\section{RÉFÉRENCES}

Brownlee C, Duddridge JA, Malibari A, Read DJ (1983) The structure and function of mycelial systems of ectomycorrhizal roots with special reference to their role in forming inter-plant connections and providing pathways for assimilate and water transport. Plant and Soil 71, 433-443

Boyd R, Furbank RT, Read DJ (1986) Ectomycorrhiza and the water relations of trees. In: Proc. $1^{\text {st }}$ Euro Symp on $M y$ corrhizae: Physiology and genetics (Gianinazzi-Pearson $Y$, Gianinazzi $S$, eds) 1-5 July 1985, Dijon INRA, Paris, 689-693

Caemmerer S, Farquhar GD (1981) Some relationships between the biochemistry of photosynthesis and the gas exchange of leaves. Planta 153, 376-387

Duddridge JA, Malibari A, Read DJ (1980) Structure and function of mycorrhizal rhizomorphs with special reference to 
their role in water transport. Nature 287 , 834-836

Ehret DL, Jolliffe PA (1985) Photosynthetic carbon dioxide exchange of bean plants grown at elevated carbon dioxide concentrations. Can J Bot 63, 2026-2030

Ekwebelam SA, Reid CPP (1983) Effect of light, nitrogen fertilization, and mycorrhizal fungi on growth and photosynthesis of lodgepole pine seedlings. Can J For Res 13, $1099-1106$

Guehl JM, Aussenac G (1987) Photosynthesis decrease and stomatal control of gas exchange in Abies Alba Mill in response to vapor pressure difference. Plant Physiol 83, 316-322

Guehl JM, Falconnet G, Gruez J (1989) Croissance, caractéristiques physiologiques et survie après plantation de plants de Cedrus atlantica élevés en conteneurs sur différents types de substrats de culture. Ann Sci For 46, 1-14

Harley JL, Smith SE (1983) Growth and Carbon metabolism of ectomycorrhizal plants. In: Mycorrhizal Symbiosis Harley $\mathrm{JL}$, Smith SE, eds) Academic Press, London 183-200

Harris GC, Cheesbrough JK, Walker DA (1983) Measurement of $\mathrm{CO}_{2}$ and $\mathrm{H}_{2} \mathrm{O}$ vapor exchange in spinach leaf disks. Plant Physiol 71, 102-107

Herold A (1978) Induction of wilting by mannose in spinach beet leaves. New Phytol 81, 299-305

Jones MD, Hutchinson TC (1988) Nickel toxicity in mycorrhizal birch seedlings infected with Lactarius rufus or Scleroderma flavidum. I. Effects on growth, photosynthesis, respiration and transpiration. New Phytol 108, 451-459

Le Tacon F, Garbaye J, Carr G (1987) The use of mycorrhizas in temperate and tropical forests. Symbiosis 3, 179-206

Marshall JD, Perry DA (1987) Basal and maintenance respiration of mycorrhizal and nonmycorrhizal root systems of conifers. Can J For Res 17, 872-877

Martin F, Ramstedt M, Söderhäll K (1987) Carbon and nitrogen metabolism in ectomycorrhizal fungi and ectomycorrhizas. Biochimie 69, 569-581
Marx DH, Bryan WC, Cordell CE (1977) Survival and growth of pine seedlings with Pisolithus ectomycorrhizae after 2 years in reforestation sites in North Carolina and Florida. Forest Sci 22, 363-373

Mousain D, Falconnet G, Gruez J, Chevalier $G$, Tillard $P$, Bousquet $N$, Plassard $C$, Cleyet-Marel JC (1988) Controlled ectomycorrhizal development of mediterranean forest seedlings in the nursery. First results and prospects. In: Proc 7th North American Conf on Mycorrhizae (Sylvia DM, Hung LL, Graham JH, eds) May 3-8 1987, Gainesville, Florida, USA

Pachlewski R (1967) Investigations of pure culture of mycorrhizal fungi of Pine (Pinus silvestris L). Forest Research Institute, Warsaw

Paul EA, Harris D, Fredeen A (1985) Carbon flow in mycorrhizae plant associations. $\mathrm{m}$ : Proc 6th North American Conf on $\mathrm{My}$ corrhizae (Molina R, ed) June 25-29 1984, Bend, Oregon, USA 165-169

Parker WC, Moorhead DJ, Pallardy SG, Garrett HE, Dixon RK (1986) Six-year field performance of container-grown and bare-root black oak seedlings inoculated with Pisolithus tinctorius and outplanted on two Ozark clear-cuts. Can J For Res 16, 1339-1345

Reid CPP, Kidd A, Eckwebelam SA (1983) Nitrogen nutrition, photosynthesis and carbon allocation in ectomycorrhizal pine. Plant Soil 71: 415-432

Stribley P, Snellgrove RC (1985) Physiological changes accompanying mycorrhizal infection in leek. In: Proc 6th North American Conf on Mycorrhizae, (Molina R, ed) June 25-29 1984, Bend, Oregon, USA 355

Tyminska A, Le Tacon F, Chadoeuf J (1986) Effect of three ectomycorrhizal fungi on growth and phosphorus uptake of Pinus silvestris seedlings at increasing phosphorus levels. Can J Bot 64, 2753-2757

Wong SC, Cowan IR, Farquhar GD (1985) Leaf conductance in relation to rate of $\mathrm{CO}_{2}$ assimilation. I. Influence of nitrogen nutrition, phosphorus nutrition, photon flux density, and ambient partial pressure of $\mathrm{CO}_{2}$ during ontogeny. Plant Physiol 78, 821-825 